\title{
The effects of thinning on the structural diversity of coppice forests
}

\author{
Fernando MonteS*, Isabel CAÑEllas, Miren DEL Río, Rafael CALAMA, Gregorio MonTERo \\ Center for Forest Research-INIA, Ctra. A Coruña km 7,5, 28040 Madrid, Spain
}

(Received 14 August 2002; accepted 26 February 2004)

\begin{abstract}
Coppices are currently at a turning point: traditional uses have been abandoned and silviculture must be redefined according to new uses. Thinning to improve the development of trees is often the silvicultural treatment chosen. This paper attempts to assess the changes in forest structural diversity induced by different thinning regimes applied in coppice stands of Quercus pyrenaica and Quercus faginea. Structural diversity is analysed through spatial pattern, crown dimensions, vertical and horizontal differentiation and foliage height diversity. Moderate and heavy thinning have similar effects on stand structure, but the effects of light thinning are quite different for both species. The spatial pattern shows a greater regularity as the intensity of the thinning regime increases. The response of $Q$. pyrenaica to thinning is noticeable both in tree height and crown diameter, whilst in the case of $Q$. faginea, trees reacted to thinning by developing epicormic sprouts on the stem from the base of the crown. Vertical differentiation shows opposite trends in both species: increasing the intensity of thinning leads to an increase in vertical differentiation with $Q$. pyrenaica, but to a greater homogenisation shortly after thinning with $Q$. faginea. A neighbourhood analysis using Gadow's differentiation index is able to provide useful information on the changes in microstructure, while foliage height diversity index can be used to describe complex changes in the vertical structure of the stand.
\end{abstract}

coppice / Quercus pyrenaica / Quercus faginea / structural diversity / thinning

Résumé - L'effet des éclaircies sur la diversité structurale des taillis. Aujourd'hui, les taillis se trouvent à une phase de changement : on a renoncé à leur usage traditionnel, et alors la sylviculture est obligée de les redéfinir selon les nouveaux usage qu'on propose. Le recours aux éclaircies pour améliorer le croissance des arbres est le traitement de préférence. Ce travail a pour but l'identification des changements qui se sont produits dans la diversité structurale du peuplement, et qui ont été induits par l'application des divers types d'éclaircies sur les taillis de Quercus pyrenaica y Quercus faginea. La diversité structurale est étudiée avec l'analyse du modèle de répartition des tiges, de la taille des cimes, de la différenciation tant horizontale que verticale et des variations de hauteur du feuillage. Les éclaircies moyennes et fortes ont à peu près le même effet sur la structure du peuplement, mais l'effet des éclaircies plus légères est bien différent dans les deux espèces. Le modèle spatial montre une plus grande régularité au fur et à mesure que l'intensité de l'éclaircie augmente. La réponse de Quercus pyrenaica à l'éclaircie est bien évidente tant en ce qui concerne la croissance en hauteur que le diamètre de la cime. Mais pour Quercus faginea, les arbres vont réagir d'une autre façon, avec l'émission de bourgeons adventifs dès la partie inférieure de la couronne. La différenciation verticale va montrer deux tendances différentes pour les deux espèces : augmenter l'intensité des éclaircies va conduire à une augmentation de la différenciation verticale pour Quercus pyrenaica, tandis que pour Quercus faginea il y aura une plus grande homogénéisation peu après l'éclaircie. Une analyse du voisinage avec l'indice de différenciation de Gadow permettra d'obtenir des informations très utiles sur les changements de la microstructure, tandis que l'indice de hauteur du feuillage peut être employé pour décrire des changements complexes sur la structure verticale du peuplement.

taillis / Quercus pyrenaica / Quercus faginea / diversité structurale / éclaircie

\section{INTRODUCTION}

The structural attributes of forest stands are increasingly recognised as being of theoretical and practical importance in the understanding and management of forest ecosystems because structure is the attribute most often manipulated to achieve management objectives following the establishment of a forest stand [10]. Moreover, structure is a readily measured surrogate for functions or for organisms that are difficult to measure directly. On the other hand, stand structure has also a value in itself, as a product (e.g. wood) or in providing a service (e.g. landscape).
Methods applied in assessing different types of diversity are as manifold as the ways of calculating measures of diversity. Furthermore, any diversity determination is relative to the conditions of the area concerned. Considering the growing conditions of central and southern Europe, structural diversity gains a comparatively higher importance, because of the low diversity of tree species, especially in mountain forests. Also, in order to characterize stand structure, several methods have been applied, based on the spatial distribution of trees (horizontal and vertical) or on other long-used indicators such as diameter distributions.

\footnotetext{
* Corresponding author: fmontes@inia.es
} 
Although there are many studies which focus on the methodology to characterize stand structure [11, 12, 14, 18, 22, 24], only few studies compare different indices of stand structure in Mediterranean forests.

Coppice forests cover more than 2400000 ha in Spain. Quercus faginea Lamk. and $Q$. pyrenaica Willd. stands represent the majority of Mediterranean coppice forests in this country. Their traditional uses were for firewood, charcoal production and grazing. Since the middle of the last century, the use of firewood and charcoal as energy resources has reduced significantly and the lack of sustainable silvicultural treatments and thinnings has lead to dense coppice forests. In such conditions the growth of saplings is low and shoots often wither during the dry season. Due to the existence of these problems in extensive areas and to the increasing interest in the implementation of direct and indirect production uses for these stands (silvopastoral uses, recreation, environmental preservation), there is an urgent need to study and manage these coppice stands. In most cases, thinning is the treatment carried out because it concentrates growth on standing trees and should result in open woodlands where cattle grazing is the main use. In the long term, openings improve crown development and acorn production and can help seedlings to establish [20].

The response of the remaining trees to thinning depends on species characteristics such as crown and root expansion rates, tree age, site characteristics and the amount of growing space released [23]. Barbour [4] suggested that thinning could accelerate the development of some features of stand structure found in late seral stage forests. The effects of thinning on yield, diameter distribution, height and diameter growth have been widely studied for coppices $[5,6,9,17]$. However, although studies have been carried out recently on $Q$. ilex [13] and $Q$. pubescens [15], changes in stand structure are not as well documented. Moreover, assessing the effect of thinning on structural diversity is very important in these Mediterranean ecosystems where structure is directly related to basic aspects of forest management such as fire risk or the presence of livestock.

The aim of this study was to analyse the effect of thinning on the structure of $Q$. faginea and $Q$. pyrenaica coppice stands and to evaluate the response in some crown features of these species to the size of openings.

\section{MATERIALS AND METHODS}

\subsection{Study site}

More than 20 years ago, CIFOR-INIA has installed permanent thinning trials in a selection of Spanish coppices comprising Mediterranean species. In this study, the experimental trials carried out with Quercus pyrenaica and Quercus faginea are analysed.

The plots chosen for $Q$. pyrenaica are situated in Navacerrada, in the Sierra de Guadarrama (Central Range of Spain), 40 43' 54" N and $4^{\circ} 0$ ' $16^{\prime \prime} \mathrm{W}$. The stand is located on a north-west facing $20 \%$ slope at an altitude of $1250 \mathrm{~m}$. The parent material is granitic and covered with a shallow, permeable soil. Mean annual rainfall is $678 \mathrm{~mm}$ and the mean temperature is $9.9^{\circ} \mathrm{C}$. The stand was two storied, the upper storey being about 40 years old and the lower about 20 . The plots, $40 \times 40 \mathrm{~m}$ in dimension, were low-thinned in 1979 with three different intensities (Tab. I). Each intensity is considered as a treatment effect.
Table I. Average number of stems per ha, basal area, mean diameter at breast height $(D b h)$ and mean height for the 3 thinning intensities carried out in $Q$. pyrenaica plots.

\begin{tabular}{lcccc}
\hline Thinning intensity & Stems/ha & $\begin{array}{c}\text { Basal area } \\
\left(\mathrm{m}^{2} / \mathrm{ha}\right)\end{array}$ & $D b h(\mathrm{~cm})$ & Height $(\mathrm{m})$ \\
\hline Light thinning & 2025 & 9.46 & 6.84 & 4.80 \\
Moderate thinning & 1000 & 6.57 & 8.11 & 5.50 \\
Heavy thinning & 721 & 4.95 & 8.35 & 5.57 \\
\hline
\end{tabular}

Table II. Average number of stems per ha, basal area, mean diameter at breast height $(D b h)$ and mean height for the 3 thinning intensities carried out in $Q$. faginea plots.

\begin{tabular}{lcccc}
\hline Thinning intensity & Stems/ha & $\begin{array}{c}\text { Basal area } \\
\left(\mathrm{m}^{2} / \mathrm{ha}\right)\end{array}$ & $\begin{array}{c}\text { Dbh } \\
(\mathrm{cm})\end{array}$ & $\begin{array}{c}\text { Height } \\
(\mathrm{m})\end{array}$ \\
\hline Light thinning & 1788 & 5.53 & 6.18 & 4.67 \\
Moderate thinning & 1025 & 4.36 & 7.18 & 5.41 \\
Heavy thinning & 750 & 2.92 & 6.85 & 5.38 \\
\hline
\end{tabular}

The experiment involved three random plots per treatment. Plots were inventoried every five years, three times from 1980 to 1990.

The plots selected for $Q$. faginea are situated in Brihuega, Guadalajara, in the foothills of the Iberian range $\left(40^{\circ} 48^{\prime} 18^{\prime \prime} \mathrm{N}\right.$ and $2^{\circ} 45^{\prime} 16^{\prime \prime} \mathrm{O}$ ), on a $20 \%$ North-west facing slope at an altitude of $850 \mathrm{~m}$. Mean annual rainfall is $570 \mathrm{~mm}$ and the mean temperature is $12.3^{\circ} \mathrm{C}$. Soils are formed from calcareous rock, with a high clay content and low permeability.

Plots are $40 \times 40 \mathrm{~m}$. Low-thinning was carried out with similar intensity levels to those in the Q. pyrenaica trial (Tab. II). In the light thinned plots one stem per stool was left, whereas in moderate and heavy thinned plots some stools were completely removed. In this case, the experiment involved two plots per treatment, and inventories were also taken every five years from 1980 to 1990 .

All the saplings were mapped in each plot. Diameter at breast height $(d b h)$, total height $(h t)$, crown diameter $(d c)$ and crown length $(l c)$ of all saplings within the plots were recorded in all the inventories.

\subsection{Methods}

\subsubsection{Stand structure characterisation}

Stand structure was characterised for each plot and inventory. In order to characterize the structure, the following aspects were taken into account:

(i) Spatial pattern

- Ripley's $K$ function

The spatial pattern was analysed using the Ripley's function $K(d)$ [26]. $K(d)$ was calculated from the equation:

$$
\lambda K(d)=\sum_{i=1}^{n} \sum_{j=1}^{n} \frac{\delta_{i j}(d)}{n}, i \neq j, \quad \delta_{i j}(d)\left[\begin{array}{ll}
1 & \text { if } d_{i j} \leq d \\
0 & \text { if } d_{i j}>d
\end{array}\right.
$$

where $\lambda$ is the density of stems per unit area, $d_{i j}$ the distance from tree $i$ to tree $j$, and $n$ the number of trees in a circular area of radius $d$. The $K$ value is compared to the expected value of a Poisson distribution obtained through 99 simulations of the Poisson process [25]. Discarding the $2.5 \%$ higher and lower values of the 99 simulations we can establish also a 95\% confidence bounds. Values of $K$ above the upper bound curve indicates there are more trees up to a distance $d$ distant 


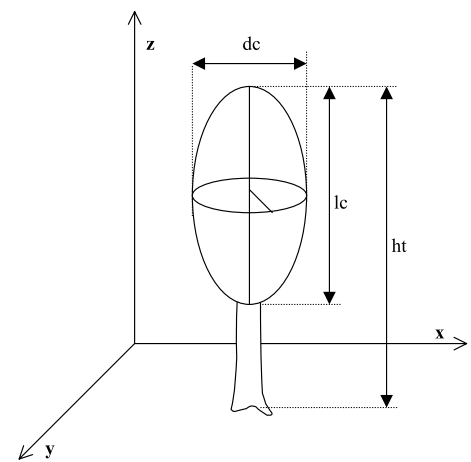

Figure 1. Single tree variables use to characterize the canopy stratum; $h t$ : total height, $d c$ : crown diameter and $l c$ : crown lenght. To estimate the relative abundance of foliage in each stratum for the FHD calculation, the crown of the trees was considered as an ellipsoid of revolution with $z$ axis as revolution axis.

those expected under random distribution, so the spatial pattern is cluster. The transformation $\hat{L}(d)$ proposed by Besag in the discussion of Ripley paper [25] was used. This transformation linearizes and stabilizes the variance of the $K$ function:

$$
\hat{L}(d)=\sqrt{\frac{\hat{K}(d)}{\pi}-d} .
$$

- Gadow's uniform angle index $\left(I_{G}\right)$.

The spatial pattern was also analysed using Gadow's uniform angle index [12]:

$$
I_{G i}=\frac{1}{n} \cdot \sum_{j=1}^{n} z_{i j} \quad z_{i j}\left[\begin{array}{ll}
1 & \text { if } w_{i j} \leq w \\
0 & \text { if } w_{i j}>w
\end{array}\right.
$$

where $n$ is the number of neighbours considered (in this case $n=3$ ), $w_{i j}$ is the angle formed by the two lines issued from a reference tree and going through $i$ and $j$ neighbours and $w$ is the ratio of $360^{\circ}$ to $n$. If stems were very uniformly distributed, $w_{i j}$ should be more wide than under clumped distribution, so $I_{G i}=1$ indicates that the trees in the neighbourhood of the reference tree are clumped, $I_{G i}=0$ indicates a regular distribution of trees [1].

(ii) Canopy features

To characterize the canopy stratum of the plots, the following single tree variables were computed (see Fig. 1)

- Total height of all the stems in the plot $\left(h_{t}\right)$.

- Crown diameter of all stems in the plot $\left(d_{c}\right)$, calculated averaging two perpendicular measures of the crown width, using fixed directions for all the trees.

- Crown length of all stems in the plot $\left(l_{c}\right)$, calculated as the difference of the total height to the height of the lower alive branch.

- The crown ratio calculated for each stem $(c r)$ as the ratio between crown length and total height.

(iii) Vertical and horizontal size differentiation was analysed in each plot using Gadow's differentiation index [12]:

$$
T D n=\frac{1}{N} \sum_{i=1}^{N} T D n_{i}
$$

with

$$
T D n_{i}=\frac{1}{n} \sum_{j=1}^{n}\left(1-\frac{x_{\min }}{x_{\max }}\right)_{j}
$$

where $T D n$ is the mean differentiation calculated with $n$ neighbours, $N$ the number of trees analysed per plot, $T D n_{i}$ the differentiation index for tree $i$ calculated with $n$ neighbours, $x_{\min }$ and $x_{\max }$ are the smallest and the largest diameters (horizontal differentiation) or heights (ver- tical differentiation) among tree $i$ and its $n$ neighbours. As the usual practice is to take into consideration the three nearest neighbours [11], $n$ was set to 3 in the calculations. The differentiation index gives a quantification of the variation at microstructure level (the neighbourhood of a tree), where many ecological processes take place. TDn ranges from 0 to 1 . Values close to 0 indicate that the neighbours are very similar sized to the reference tree, whereas values close to 1 indicate high differentiation.

(iv) Foliage height diversity ( $F H D$ ) [16] was estimated for each plot using the Shannon index to characterize the distribution of the tree crowns in vertical strata:

$$
F H D=-\sum p_{i} \cdot \ln \left(p_{i}\right)
$$

where $p_{i}$ is the relative abundance of foliage in strata $i$. To estimate the relative abundance of foliage, the crown of trees was considered as an ellipsoid of revolution (Eq. (7)), being the generatrix an ellipse with the $z$ axis equal to crown length and the $x$ axis equal to crown diameter (Fig. 1).

$$
\frac{x^{2}+y^{2}}{\left(d_{c} / 2\right)^{2}}+\left(\frac{z-\left(h_{t}-l_{c} / 2\right)}{l_{c} / 2}\right)^{2}=1
$$

where $d_{c}$ is the crown diameter, $l_{c}$ is the crown length and $h_{t}$ is the total height of the tree.

$$
\begin{aligned}
& \text { Making } z \equiv h \text { and } \\
& r^{2}=x^{2}+y^{2}=\left(d_{c} / 2\right)^{2}-\frac{\left(d_{c} / 2\right)^{2} \cdot\left[h-\left(h_{t}-l_{c} / 2\right)\right]^{2}}{\left(l_{c} / 2\right)^{2}}
\end{aligned}
$$

the ellipsoid volume for a given tree was calculated within each height strata $i$ through the following integral:

$$
V_{i}=\int_{h_{i 1}}^{h_{i 2}} \pi \cdot r^{2} d h
$$

where $V_{i}$ is the crown volume of the tree in the strata $i$ (from height $h_{i 1}$ to $h_{i 2}$ ). Four strata were defined: the lower strata ranged from ground to $h=0.7 \mathrm{~m}$, the second strata from 0.7 to $2 \mathrm{~m}$, the third from 2 to $5 \mathrm{~m}$ and the upper strata above $h=5 \mathrm{~m}$. The relative abundance of foliage in strata $i\left(p_{i}\right)$ has been approximated as:

$$
p_{i}=\sum_{j=1}^{N} V_{j i} / \sum_{i=1}^{4} \sum_{j=1}^{N} V_{j i}
$$

where $N$ is the number of trees within the plot. The more equally the crowns are distributed among the four strata, the higher is the $F H D$ value.

A graphical analysis was performed to evaluate the trend of the analysed variables $\left(h_{t}, d_{c}, c r, T D d 3, T D h 3\right.$ and $F H D$, being $T D d 3$ and $T D h 3$ respectively horizontal and vertical differentiation indices with $n=3$ ) through the inventories.

\subsubsection{Statistical methods}

Since three inventories were carried out at each plot, the effect of thinning intensity was evaluated using a repeated measurements analysis of variance (RMANOVA) following the SAS procedure GLM [21, 27]. Tested variables were both single tree (canopy features) and plot variables (differentiation and diversity indices). The general expression for a single factor RMANOVA is:

$$
Y_{i j k}=\mu+T_{j}+\gamma_{k}+T \cdot \gamma_{j k}+\varepsilon_{i j k}
$$

where $Y_{i j k}$ is the observed value for the response variable $Y$ on the $\mathrm{i}_{\text {th }}$ sample (tree or plot) under treatment $j$ taken during the $k_{\mathrm{th}}$ inventory; $\mu$ is the overall mean value for the response variable $Y ; T$ is the treatment effect, in this case, thinning intensity; $\gamma$ is the time (inventory) effect; $T \times \gamma$ is the time $\times$ treatment interaction effect and $\varepsilon_{\mathrm{ijk}} \sim \mathrm{N}(0, \sigma)$ indicates the random error terms, with variance-covariance matrix $\sigma$. Mauchly's criterion test for the compound symmetry of the variancecovariance matrix was carried out for all the analysed variables. 


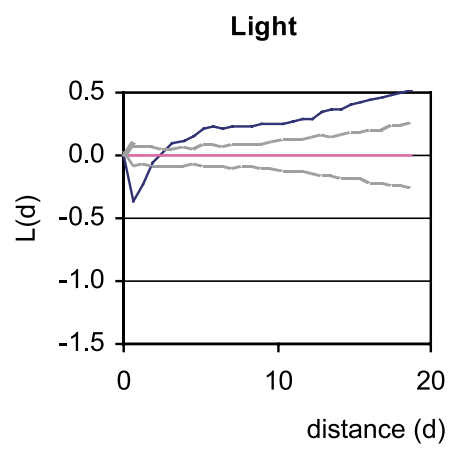

a

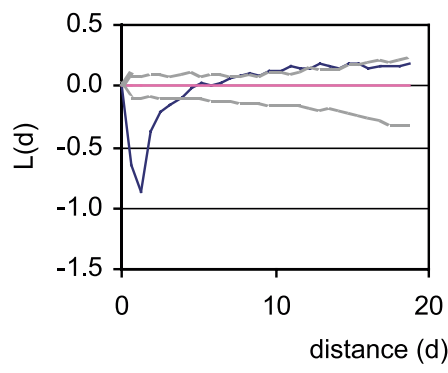

b

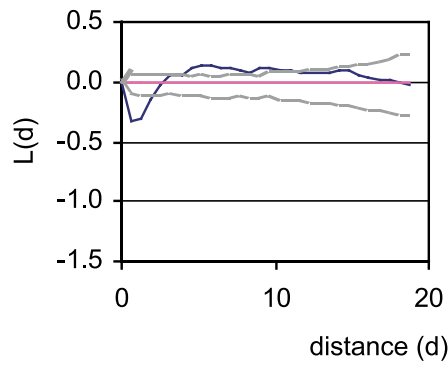

c
Moderate

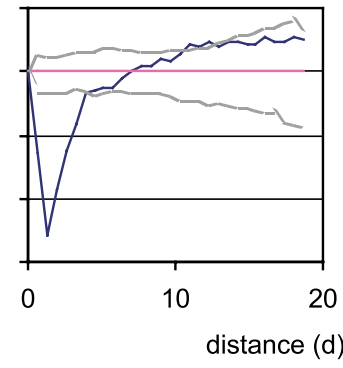

d
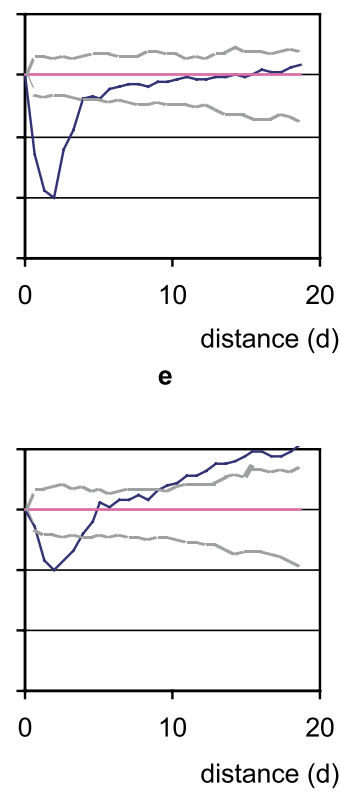

f
Heavy

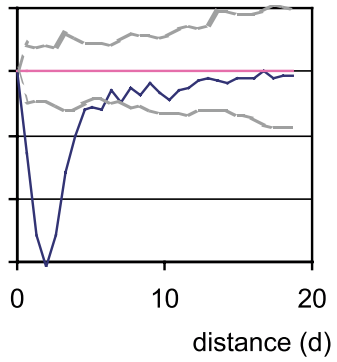

g

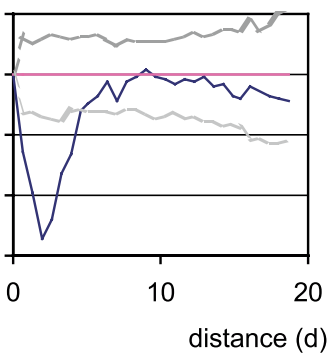

h

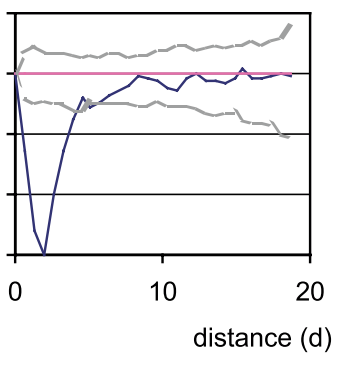

g

Figure 2. Analysis of the spatial pattern of trees in $Q$. pyrenaica plots (a, $\mathbf{b}$ and $\mathbf{c}$ : light thinning; $\mathbf{d}, \mathbf{e}$ and $\mathbf{f}:$ moderate thinning; $\mathbf{g}, \mathbf{h}$ and $\mathbf{i}:$ heavy thinning; 3 plots for each thinning treatment) using the transformation $L(d)$ of Ripley's function $K(d)$. Solid lines: $K$ function value for the real distribution of trees; grey lines: $90 \%$ confidence interval boundaries of $L(d)$ for a Poisson distribution.

Hypothesis of sphericity was only accepted for the Gadow's differentiation index applied to diameter and height and for $F H D$. In order to evaluate treatment effect between samples, a null-hypothesis test was used since it does not require a sphericity condition. As the sphericity hypothesis for the variance-covariance matrix was not accepted for all variables, a multivariate approach was followed using Roy's greatest root test to assess the significance of time and time $\times$ treatment effect $[21,27]$.

The existence of significant differences between treatments within the same inventory was evaluated following a univariate ANOVA. Tukey's test of multiple range was used to analyse the differences among treatments (95\% significance level).

\section{RESULTS}

\subsection{Spatial pattern}

The spatial patterns of trees studied through the transformation $\hat{L}(d)$ of Ripley's $K$ function are presented in Figures 2 and 3 .
Light lines indicate $90 \%$ confidence interval boundaries for the function $\hat{L}(d)$ of a Poisson distribution. When the $\hat{L}(d)$ function for the real distribution of trees (bold line) falls above the upper boundary confidence interval, this denotes a clustered distribution; if it falls under the lower boundary, the distribution is regular.

The analysis through Ripley's function $K(d)$ shows that the heavier the thinning, the longer is the range of regular pattern for both species. Clustered distribution was found in lightly thinned plots above a distance of 3 to $10 \mathrm{~m}$ in the case of $Q$. pyrenaica (Fig. 2). This trend is steeper in plot 1a, which has also the highest density (2.462 stems/ha). Plot 1f (moderately thinned) shows also a clustered pattern.

Clustered distribution above $7 \mathrm{~m}$ was only found in one of the lightly thinned $Q$. faginea plots (Fig. 3b) and a cluster pattern was found again in one of the heavily thinned plots above a distance of $10 \mathrm{~m}$ (Fig. 3e). 
Light

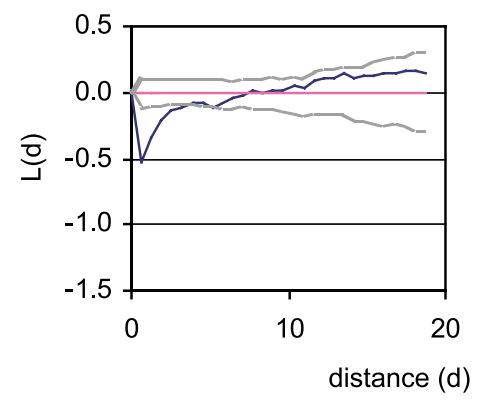

a

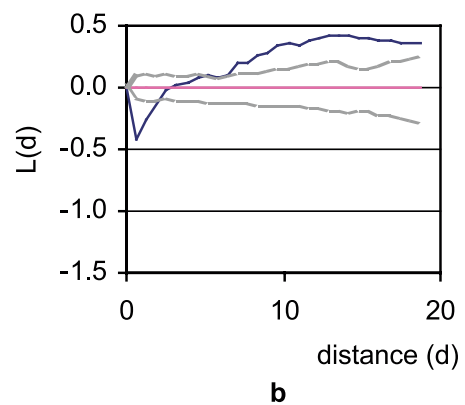

Moderate
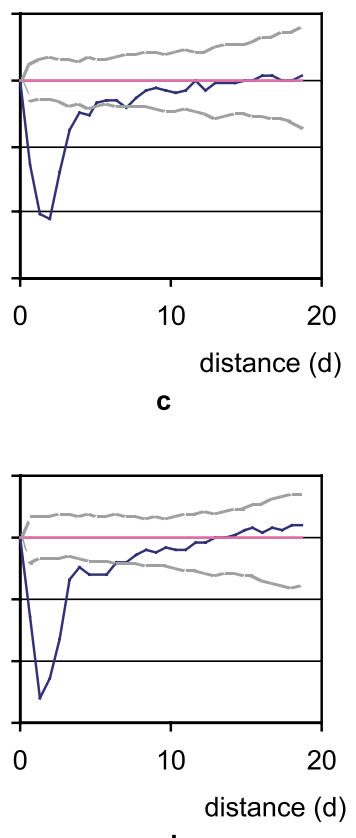

d
Heavy

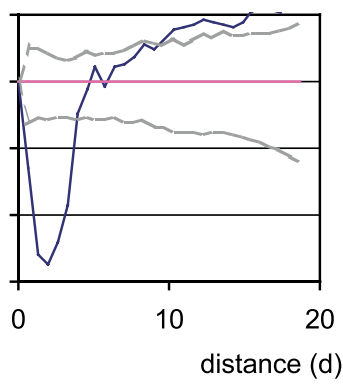

e

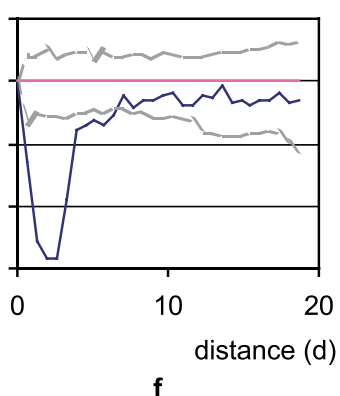

Figure 3. Analysis of the spatial pattern of trees in $Q$. faginea plots (a and $\mathbf{b}$ : light thinning; $\mathbf{c}$ and $\mathbf{d}$ : moderate thinning; $\mathbf{e}$ and $\mathbf{f}$ : heavy thinning; 2 plots for each treatment) using the transformation $L(d)$ of Ripley's function $K(d)$. Solid lines: $K$ function value for the real distribution of the trees; grey lines: $90 \%$ confidence interval boundaries of $L(d)$ of a Poisson distribution.

Table III. Mean value for each thinning intensity of Gadow's uniform angle index. Values from 0 to 0.33 indicate a regular pattern, from 0.33 to 0.66 a random pattern and above 0.66 an irregular pattern.

\begin{tabular}{lcc}
\hline Thinning intensity & Q. pyrenaica & Q. faginea \\
\hline Light & 0.60 & 0.63 \\
Moderate & 0.60 & 0.59 \\
Heavy & 0.58 & 0.57 \\
\hline
\end{tabular}

Gadow's uniform angle index shows a random pattern in all plots, with a mean value of 0.59 for $Q$. pyrenaica and a mean value of 0.60 for $Q$. faginea (Tab. III).

\subsection{Canopy features}

The repeated measurements analysis of variance shows that significant differences exist between the three thinning intensities for all studied canopy variables in both trials. Time effect and time $\times$ treatment interaction are also significant for all variables (Tab. IV). Height and height increment, crown length and increment, as well as crown diameter and its increment tend to be lower for both species as thinning intensity decreases (Fig. 4). However, differences between treatments are not statistically significant in all inventories (Tab. V).

In the $Q$. pyrenaica trial, the first inventory suggests that light thinning produces a significantly lower value for height, crown length and crown diameter than moderate or heavy thinning. The differences between the treatments increase over time (Tab. V). The relationship between thinning intensity and crown ratio shows a similar trend although significant differences disappear for the last inventory.

In the first inventory, just after thinning, results in the $Q$. faginea trial are not so clear. Crown ratio and crown diameter return significantly higher values for light thinning (Fig. 4). However, the differences among treatments increase over time, with values increasing with the intensity of thinnings (Tab. V).

The greatest difference between the two species regarding canopy behaviour, is that just after thinning $Q$. faginea develops epicormic shoots, leading to a very step increase of crown ratio. However, in the $Q$. pyrenaica trial the crown ratio shows a low increment just after thinning, although it increases moderately in the second interval.

\subsection{Vertical and horizontal size differentiation}

For $Q$. pyrenaica, no significant differences between thinning intensities were found in $T D h 3$, but a time $\times$ treatment significant effect was noted (for Roy's greatest root $\operatorname{Pr}<\mathrm{F}=$ 0.0047) (Tab. IV). Time and time $\times$ treatment effects are highly significant for $T D d 3$, furthermore treatment effect is also significant at 0.05 level for this variable. In the first inventory, the values for horizontal and vertical differentiation were lower after light thinning than after moderate or heavy thinnings (Fig. 5). Nevertheless, the lightly thinned plots show a trend towards rising differentiation while in the case of moderately and heavily thinned plots the differentiation tends to decrease with time. In the third inventory, most of the heavily thinned plots show lower vertical differentiation values than the others. 
Table IV. Tests of hypotheses for treatment (tr), time and time $\times$ treatment effects in Repeated Measures Analysis of Variance. Pr $<$ F indicates the level of significance for the null hypothesis of no difference between effects. TDh3 and TDd3 are Gadow's differentiation index calculated using three neighbours for height and diameter respectively. FHD is the foliage height diversity index.

\begin{tabular}{|c|c|c|c|c|c|c|c|}
\hline & \multirow[t]{2}{*}{ Variable } & \multicolumn{3}{|c|}{ Q. pyrenaica $\operatorname{Pr}<\mathrm{F}$} & \multicolumn{3}{|c|}{ Q. faginea $\operatorname{Pr}<\mathrm{F}$} \\
\hline & & $\operatorname{tr}$ & time & time $\times \operatorname{tr}$ & $\operatorname{tr}$ & time & time $\times \operatorname{tr}$ \\
\hline \multirow[t]{4}{*}{ Tree - level variables } & Height & $<0.0001$ & $<0.0001$ & $<0.0001$ & $<0.0001$ & $<0.0001$ & $<0.0001$ \\
\hline & Crown length & $<0.0001$ & $<0.0001$ & $<0.0001$ & $<0.0001$ & $<0.0001$ & $<0.0001$ \\
\hline & Crown ratio & $<0.0001$ & $<0.0001$ & $<0.0001$ & 0.0006 & $<0.0001$ & $<0.0001$ \\
\hline & Crown diameter & $<0.0001$ & $<0.0001$ & $<0.0001$ & $<0.0001$ & $<0.0001$ & $<0.0001$ \\
\hline \multirow[t]{3}{*}{ Plot - level variables } & $T D h 3$ & 0.2448 & 0.0262 & 0.0047 & 0.0238 & 0.1408 & 0.2104 \\
\hline & $T D d 3$ & 0.0393 & 0.0002 & 0.0037 & 0.1285 & 0.0378 & 0.0221 \\
\hline & $F H D$ & 0.4288 & 0.0500 & 0.4477 & 0.0498 & 0.0036 & 0.0514 \\
\hline
\end{tabular}

Quercus pyrenaica
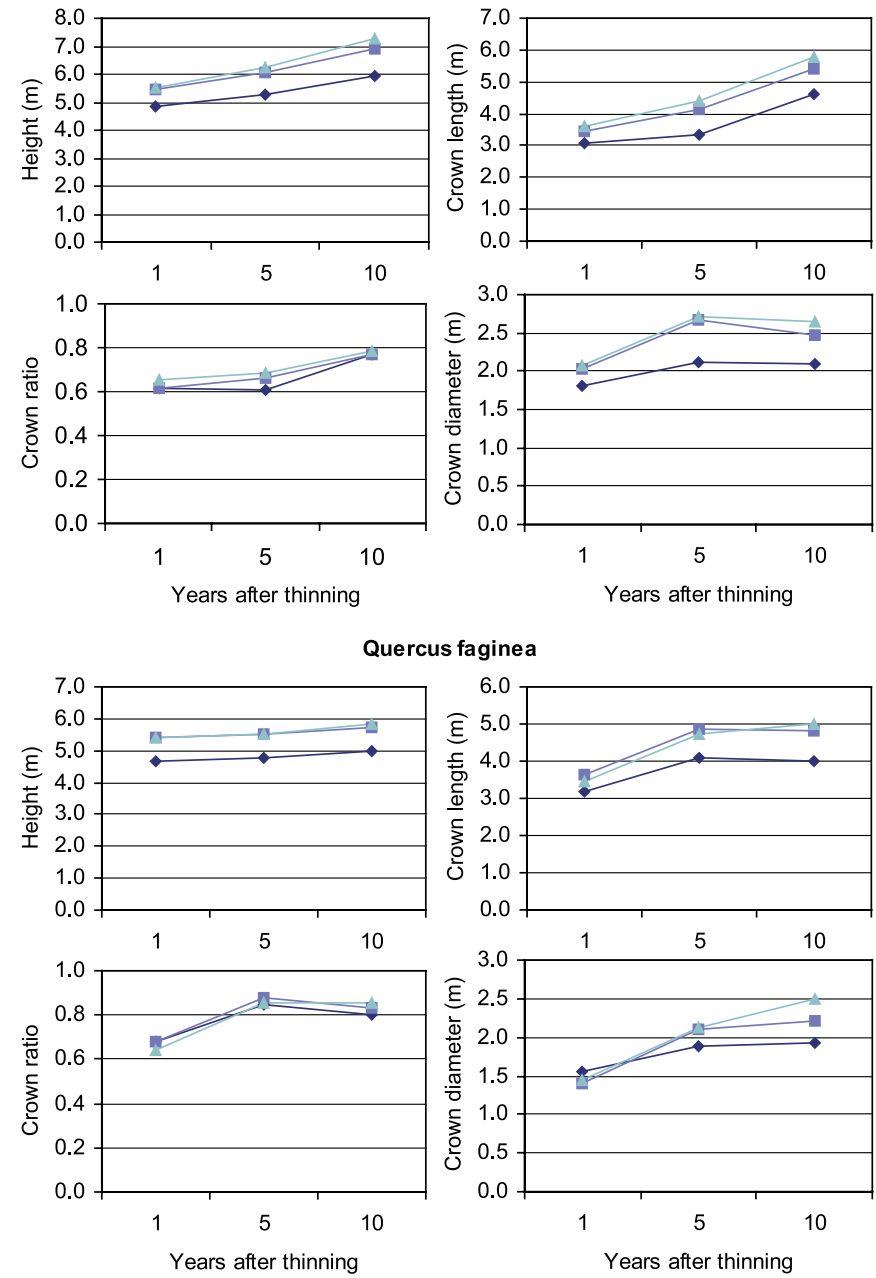

$\rightarrow$ Light thinning $\rightarrow-$ Moderate thinning $\rightarrow-$ Heavy thinning

Figure 4. Evolution of height (m), crown length (m), crown ratio and crown diameter $(\mathrm{m})$ with time (years after thinning) for $Q$. pyrenaica plots (above) and for $Q$. faginea plots (below).

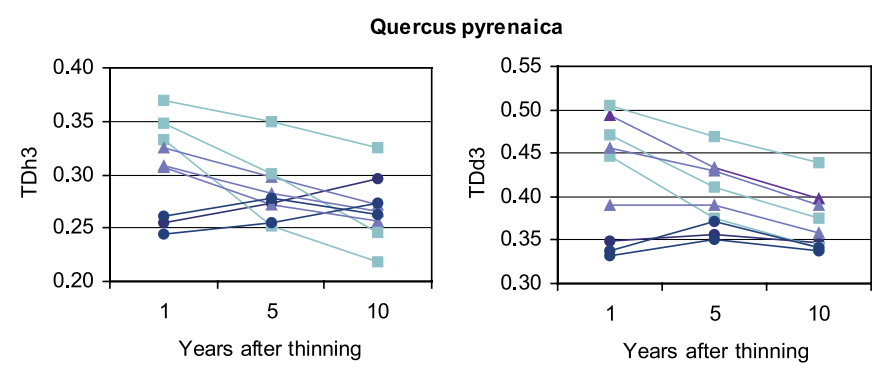

Quercus faginea
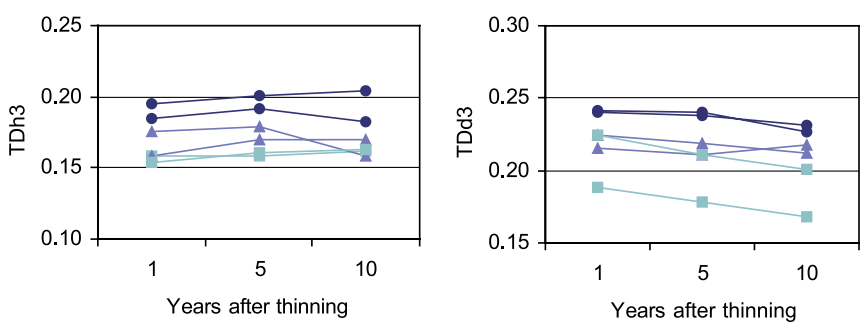

- Light thinning $\rightarrow-$ Moderate thinning - Heavy thinning

Figure 5. Evolution of Gadow's differentiation index calculated using three neighbours for height (TDh3) and diameter (TDd3) in $Q$. pyrenaica plots (above) and in Q. faginea plots (below). Different plots have been represented by different lines to show same treatment variability.

Significant differences were found with $Q$. faginea for $T D h 3$ at 0.05 level depending on which thinning regime was applied (Tab. V). However, this was not the case for $T D d 3$. Plots where light thinning was carried out have higher horizontal and vertical differentiation, while heavily thinned plots return the lowest values (Fig. 5). Furthermore, in the first five years after thinning, vertical differentiation increases in all plots, whereas the opposite occurs with horizontal differentiation, which shows a decreasing trend for 10 years after treatment. (Fig. 5). Nevertheless, the variations over time are lower than for $Q$. pyrenaica. 
Table V. Significant differences at 0.001 level between treatments for each inventory time (time 1: just after thinning; time $2: 5$ years after thinning; time 3: 10 years after thinning) evaluated through a univariate ANOVA.

\begin{tabular}{|c|c|c|c|c|c|c|c|c|}
\hline & \multirow[b]{2}{*}{ Variable } & \multirow[b]{2}{*}{ Treatment } & \multicolumn{3}{|c|}{$Q$. pyrenaica } & \multicolumn{3}{|c|}{ Q. faginea } \\
\hline & & & Time 1 & Time 2 & Time 3 & Time 1 & Time 2 & Time 3 \\
\hline \multirow[t]{12}{*}{ Tree - level variables } & Height & Light & $\mathrm{a}$ & $\mathrm{a}$ & a & $\mathrm{a}$ & $\mathrm{a}$ & $\mathrm{a}$ \\
\hline & & Moderate & $\mathrm{b}$ & $\mathrm{b}$ & $\mathrm{b}$ & $\mathrm{b}$ & $\mathrm{b}$ & $\mathrm{b}$ \\
\hline & & Heavy & $\mathrm{b}$ & $\mathrm{b}$ & $\mathrm{c}$ & $\mathrm{b}$ & $\mathrm{b}$ & $\mathrm{b}$ \\
\hline & Crown length & Light & $\mathrm{a}$ & $\mathrm{a}$ & $\mathrm{a}$ & $\mathrm{a}$ & $\mathrm{a}$ & $\mathrm{a}$ \\
\hline & & Moderate & $\mathrm{b}$ & $\mathrm{b}$ & $\mathrm{b}$ & $\mathrm{c}$ & $\mathrm{b}$ & $\mathrm{b}$ \\
\hline & & Heavy & $\mathrm{b}$ & $\mathrm{b}$ & $\mathrm{c}$ & $\mathrm{b}$ & $\mathrm{b}$ & $\mathrm{b}$ \\
\hline & Crown ratio & Light & $\mathrm{a}$ & $\mathrm{a}$ & $\mathrm{a}$ & $\mathrm{b}$ & a & $\mathrm{a}$ \\
\hline & & Moderate & $\mathrm{a}$ & $\mathrm{b}$ & $\mathrm{a}$ & $\mathrm{b}$ & $\mathrm{b}$ & $\mathrm{b}$ \\
\hline & & Heavy & $\mathrm{b}$ & $\mathrm{b}$ & $\mathrm{a}$ & $\mathrm{a}$ & $\mathrm{a}$ & $\mathrm{c}$ \\
\hline & Crown diameter & Light & a & $\mathrm{a}$ & $\mathrm{a}$ & $\mathrm{b}$ & $\mathrm{a}$ & $\mathrm{a}$ \\
\hline & & Moderate & $\mathrm{b}$ & $\mathrm{b}$ & $\mathrm{b}$ & $\mathrm{a}$ & $\mathrm{b}$ & $\mathrm{b}$ \\
\hline & & Heavy & $\mathrm{b}$ & $\mathrm{b}$ & $\mathrm{c}$ & $\mathrm{a}$ & $\mathrm{b}$ & $\mathrm{c}$ \\
\hline \multirow[t]{9}{*}{ Plot - level variables } & TDh3 & Light & $\mathrm{a}$ & $\mathrm{a}$ & $\mathrm{a}$ & $\mathrm{a}$ & $\mathrm{a}$ & $\mathrm{a}$ \\
\hline & & Moderate & $\mathrm{b}$ & $\mathrm{a}$ & $\mathrm{a}$ & a & $a b$ & $\mathrm{a}$ \\
\hline & & Heavy & $\mathrm{c}$ & a & $\mathrm{a}$ & $\mathrm{a}$ & $\mathrm{b}$ & $\mathrm{a}$ \\
\hline & $T D d 3$ & Light & $\mathrm{a}$ & $\mathrm{a}$ & $\mathrm{a}$ & $\mathrm{a}$ & $\mathrm{a}$ & $\mathrm{a}$ \\
\hline & & Moderate & $\mathrm{b}$ & $\mathrm{a}$ & $\mathrm{a}$ & $\mathrm{a}$ & $\mathrm{a}$ & $\mathrm{a}$ \\
\hline & & Heavy & $\mathrm{b}$ & $\mathrm{a}$ & $\mathrm{a}$ & $\mathrm{a}$ & $\mathrm{a}$ & $\mathrm{a}$ \\
\hline & $F H D$ & Light & $\mathrm{a}$ & $\mathrm{a}$ & $\mathrm{a}$ & $\mathrm{a}$ & $\mathrm{a}$ & $\mathrm{a}$ \\
\hline & & Moderate & $\mathrm{a}$ & $\mathrm{a}$ & $\mathrm{a}$ & $\mathrm{a}$ & $\mathrm{a}$ & $a b$ \\
\hline & & Heavy & $\mathrm{a}$ & $\mathrm{a}$ & $\mathrm{a}$ & a & $\mathrm{a}$ & $\mathrm{b}$ \\
\hline
\end{tabular}

Treatments with the same letter indicate non significant differences for the studied variable in the period.

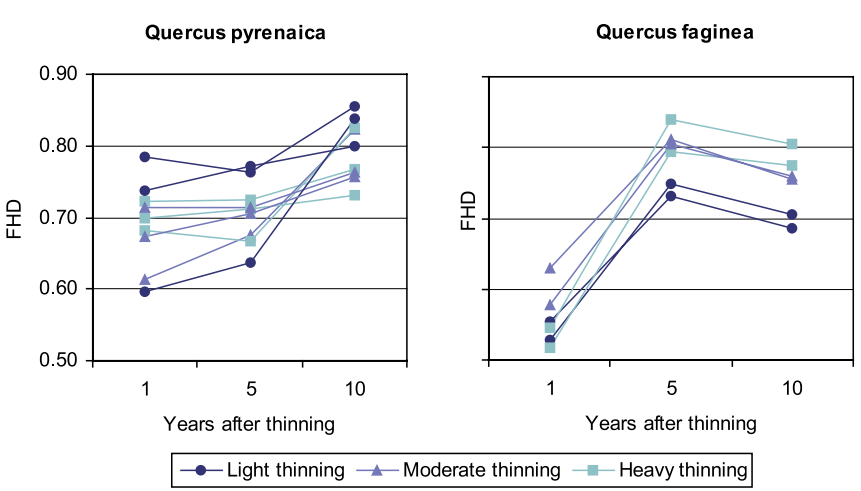

Figure 6. Evolution of foliage height diversity $(F H D)$ calculated through Shannon index with four vertical strata (lower strata comprises from ground to $0.7 \mathrm{~m}$ height, second from 0.7 to $2 \mathrm{~m}$, third from 2 to $5 \mathrm{~m}$ and upper strata above $5 \mathrm{~m}$ height) for $Q$. pyrenaica plots (left) and for $Q$. faginea plots (right).

\section{4. $F H D$}

The thinning regime used for $Q$. pyrenaica had no significant effect on FHD (Tab. IV). The rate of increase in FHD is slightly higher for the second period. The highest $F H D$ values in all the inventories corresponds to lightly thinned plots (Fig. 6).

For $Q$. faginea the effect of treatment is significant at 0.05 level (Tab. IV). The plots where moderate thinning was carried out return the highest $F H D$ values just after thinning (Fig. 6). The $F H D$ values rises up after thinning but tend to decrease in the second period. This trend is steeper for heavy thinning. The lightly thinned plots have the lowest $F H D$ values in the third inventory.

\section{DISCUSSION AND CONCLUDING REMARKS}

In both trials, a similar response to thinning was found for height and diameter growth [5]. Both trials are situated on low quality sites, so growth response is smaller than that obtained in other thinning trials with the same [6], or different species [13, 17].

Lower values for height growth is common in coppices located on poor sites, as the locality of the $Q$. faginea plots, where there is a stagnation of height growth.

Although it was expected that the range of regular pattern in short distances would increase with thinning intensity, a clustered pattern at distances around $10 \mathrm{~m}$ in lightly thinned plots was unexpected. This clustered pattern could be due to the variability of site conditions or to factors related to regeneration processes, such as capability to root sprouting and to colonise small gaps. The spatial pattern did not change over the three inventories because of the low mortality rate. Gadow's uniform angle index did not reveal any differences between treatments because the main differences are related to the scale of the pattern. In fact, very similar results were found for the uniform angle index in Scots pine forests with a much lower density [19].

As can be observed in Figure 4, the response of the crown to thinning is different in each of the studied species. Thinning 
increases the illumination on the stems and in the case of $Q$. faginea this produces an intense sprouting from the stem, instead of the reoccupation of openings through the horizontal expansion of the crown in other species. The development of sprouts is a characteristic of coppices, but different species behave in different ways, in fact for holm oak the effect of cleaning and thinning is similar to $Q$. faginea $[8,9]$, whereas $Q$. pyrenaica sprouts mainly from the root. By studying canopy characteristics, using vertical and horizontal size differentiation indices, the response of the stand structure to thinning can be determined.

Although the changes in horizontal structure brought about by different thinning intensities are very similar in both trials, the response of vertical structure to thinning seems to be very different. Low thinning usually leads to a more homogeneous stand [2, 3], but in the case of $Q$. pyrenaica, height differentiation just after thinning increases with the thinning intensity (Fig. 5). This means that there is a greater homogeneity between neighbour stems (microstructure) in light thinned plots, where the lower storey predominate over the upper storey, being the microstructure of moderate and heavy thinned plots more heterogeneous. This neighbourhood differentiation after moderate and heavy thinning gradually decreases with time, showing two of the heavy thinned plots the lowest $T D h$ value ten years after the thinning. In another study carried out in a one storied stand of $Q$. pyrenaica, diameter growth appeared positively correlated with diameter [6], which may indicate that big trees has advantage when filling out space after thinning. However, in our study, Gadow's differentiation index reveals the opposite tendency, i.e. the lower storey trees gets as high as the upper storey neighbours. This difference may be due to the age difference between the two storeys or to a height growth stagnation caused by limiting ecological conditions. It may be that neighbourhood analysis through Gadow's differentiation index allows us to obtain information about structural changes that are not revealed by other methods of analysis. Nevertheless, there was a steadily increase in microstructure differentiation in the lightly thinned plots after thinning, whereas the opposite trend was found with the more intensive thinning, leading to a decrease of differences between thinning regimes with time.

In the case of $Q$. faginea the differentiation is lower just after moderate and heavy thinnings, which means that the variation is greater at microstructure than between more distant stems. Following thinning, height differentiation increases, perhaps because growth is concentrated on the upper strata. Gracia and Retana [13] found that in holm oak coppices the diameter distribution becomes more regular with increased site quality. Therefore, the low quality of the $Q$. faginea plots could be the cause of the high differentiation in lightly thinned plots compared to moderately and heavily thinned ones as low thinning releases mainly small stems.

FHD measures have been widely used to asses habitat quality of forests and provides information about the occupancy of the different vertical strata by the vegetation, in contrast to Leaf Area Index $(L A I)$, which focuses on the quantification of photosynthetic surface. $F H D$ can be estimated using different vertical strata, depending on the crop features. Strata must be chosen according to the characteristics of the stand, reflecting the habitat requirements of the different organisms inhabiting the stand. MacArthur and MacArthur [16] used three vertical strata $(0-0.7 \mathrm{~m}, 0.7-7.6 \mathrm{~m}$ and more than $7.6 \mathrm{~m})$. Neuman and Starlinger [22] standardised the Shannon formula dividing it by $\log (N)(N$, number of strata). Layer boundaries were $0.2 \times$ Hmax, $0.5 H \max$ and $0.8 \times$ Hmax, (Hmax being the maximum height on the plot). When studying successional changes in $Q$. pubescens coppices Debussche [7] found that the following vertical stratification was suitable for the study: ground level to $0.25 \mathrm{~m}$, 0.25 to $0.5 \mathrm{~m}, 0.5$ to $1 \mathrm{~m}, 1$ to $2 \mathrm{~m}, 2$ to $4 \mathrm{~m}, 4$ to $8 \mathrm{~m}$ and more than $8 \mathrm{~m}$. The most remarkable effect that the thinnings had on the FHD of the studied stands is the increase noticed in $Q$. faginea plots just after thinning (Fig. 6), due, as previously stated, to the epicornic sprouts that appear on the lower part of the tree.

The results of this study show the importance of including individual tree features, microstructure and vertical and horizontal stand complexity in the analysis in order to correctly interpret structural changes and the effect of thinning intensity on stand structure. These changes are of great importance for forest management. For the studied species, moderate and heavy thinning improve the illumination of the crown and the forest floor vegetation, which may improve grazing production. The decrease foliage height diversity for $Q$. pyrenaica with these thinning regimes reduce fire risk, but may be undesirable for hunting or wildlife oriented management, because the animal refuge function of multi-layered stands. For $Q$. faginea the moderate and heavy thinning regimes leads to a trunk sprouting, so fire risk may increase because the vertical continuity of combustible, although the open canopy reduces the horizontal continuity.

Acknowledgements: The authors wish to thank to A. Bachiller and J.L. Montoto for their work in the inventories.

\section{REFERENCES}

[1] Aguirre O., Hui G., Gadow K.v., Jiménez J., An analysis of spatial forest structure using neighbourhood-based variables, For. Ecol. Manage. (2003) 137-145.

[2] Aguirre O., Kramer H., Jiménez J., Strukturuntersuchungen in einem Kiefern-Durchforstungsversuch Nordmexikos, Allg. Forst.u. J.-Ztg. 169 (1998) 213-219.

[3] Albert M., Gadow K.v., Kramer H., Zur Strukturbeschreibung in Douglasien-Jungbeständen am Beispiel der Versuchsflächen Manderscheid und Uslar, Allg. Forst.-u. J.-Ztg. 166 (1995) 205-210.

[4] Barbour R.J., Johnston S., Hayes J.P., Tucker G.F., Simulated stand characteristics and wood product yields from Douglas-fir plantations managed for ecosystem objectives, For. Ecol. Manage. 91 (1997) 205-219.

[5] Cañellas I., Montero G., San Miguel A., Montoto J.L., Bachiller A., Transformation of coppice of rebollo (Quercus pyrenaica Willd.) into open woodlands by thinning at different intensities. Preliminary results, Invest. Agrar. Sist. Recur. For. Fuera de serie 3 (1994) 71-78.

[6] Cañellas I., del Rio M., Roig S., Montero G., Growth response to thinning in Quercus pyrenaica Willd. coppice stands in Spanish Central Mountain, Ann. For. Sci. 61 (2004) 243-250.

[7] Debussche M., Changes in the vegetation of Quercus pubescens woodland after cessation of coppicing and grazing, J. Veg. Sci. 12 (2001) 81-92.

[8] Ducrey M., Boisserie M., Recru naturel dans des taillis de chêne vert (Quercus ilex L.) à la suite d'exploitations partielles, Ann. Sci. For. 49 (1992) 91-109. 
[9] Ducrey M., Toth J., Effect of cleaning and thinning on height growth and girth increment in holm oak coppices, Vegetatio 99100 (1992) 365-376.

[10] Franklin J.F., Spies T.A., Pelt R.V., Carey A.B., Thornburgh D.A., Berg D.R., Lindenmayer D.B., Harmon M.E., Keeton W.S., Shaw D.C., Bible K., Chen J., Disturbances and structural development of natural forest ecosystems with silvicultural implications, using Douglas-fir forests as an example, For. Ecol. Manage. 155 (2002) 399-423.

[11] Füldner K., Zur Strukturbeschreibung in Mischbeständen, Forstarchiv 66 (1995) 235-240.

[12] Gadow K.v., Zur Bestandesbeschreibung in der Forsteinrichtung, Forst und Holz 21 (1993) 601-606.

[13] Gracia M., Retana J., Effect of site quality and thinning management on the structure of holm oak forests in northeast Spain, Ann. Sci. For. 53 (1996) 571-584.

[14] Kuuluvainen T., Penttinen A., Leinonen L., Nygren M., Statistical opportunities for comparing stand structural heterogeneity in managed and primeval forests: an example from boreal Spruce forest in Southern Finland, Silva Fenn. 30 (1996) 315-328.

[15] Logli F., Joffre R., Individual variability as related to stand structure in a Mediterranean oak coppice, For. Ecol. Manage. 142 (2001) 53-63.

[16] MacArthur R.M., Mac Arthur J.W., On bird species diversity, Ecology 42 (1961) 594-598.
[17] Mayor X., Rodà F., Growth response of holm oak (Quercus ilex L.) to commercial thinning in the Montseny mountains (NE Spain), Ann. Sci. For. 50 (1993) 247-256.

[18] Moeur M., Characterizing spatial patterns of trees using stem-mapped data, For. Sci. 39 (1993) 756-775

[19] Montes F., Cañellas I., Río M.d., Montero G., The effects of silviculture on the structure of Scots pine stands in Spain, in: Proceedings of Towards the sustainable use of Europe's forests, Tours, France, 2003.

[20] Montoya J.M., Usos alternativos y conservación de los rebollares de $Q$. pyrenaica Willd., Boletín de la Estación Central de Ecología 12 (1983) 35-42.

[21] Moser E.B., Saxton A.M., Pezeshki S.R., Repeated measures analysis of variance: application to tree research, Can. J. For. Res. 20 (1990) 524-535.

[22] Neuman M., Starlinger F., The significance of different indices for stand structure and diversity in forest. For. Ecol. Manage. 145 (2001) 91-106.

[23] Oliver C.D., Larson B.C., Forest stands dynamics, McGraw-Hill, USA, 1990.

[24] Pielou E.C., Mathematical Ecology, John Wiley \& Sons, 1977.

[25] Ripley B.D., Modelling spatial patterns (with discussion), J.R. Stat. Soc. 2 (1977) 172-212.

[26] Ripley B.D., Spatial statistics, John Wiley \& Sons, New York, 1981.

[27] Sas I.I., Sas/Statlm users guide, Release 6.03 edition, Cary, USA, 1988. 